\title{
Review
}

\section{Public trials: Burke, Zola, Arendt, and the politics of lost causes}

\author{
Lida Maxwell \\ Oxford University Press, New York, 2016, 256pp., ISBN: 0190649844
}

Contemporary Political Theory (2017) 16, 570-573. doi:10.1057/s41296-017-0088-0; advance online publication 6 February 2017

A well-chosen title is a great gift to the reader and this one carries an ingenious double allusion. In the first place, it refers to the fact that criminal proceedings, despite the fact that they are, strictly speaking, matters of and for the law, can sometimes take on political significance for the public at large. Whether because the crime in question is exceptional or because a high-profile figure gets involved, some trials escape the confines of the courtroom and turn into forms of public theatre where citizens are interpellated as jurors. Trials for the public (as spectators of drama) can, however, also function as trials of the public (as agents of justice). Whether because it is somehow implicated in the wrongdoing or because it is called upon to secure a justice that exceeds the law, "the public" can find its own character being tried and tested. In cases of this kind, the stakes are unusually high because it is not just the guilt of the accused that is in issue, but the integrity of the public and thus, by implication, the merit of democracy as a political system. What is one to conclude when the public fails its trial and evil wins out?

In this terrific book, Lida Maxwell treats the prosecutions of Warren Hastings, Albert Dreyfus and Adolf Eichmann as instances of this kind of public trial. In each case, the court was presented with a crime that exceeded existing legal frameworks in the case of Hastings, "crimes against a people", in the case of Dreyfus, "crimes against society", and in the case of Eichmann, "crimes against humanity" - and in each case a public intellectual - Edmund Burke, Émile Zola and Hannah Arendt, respectively - appealed to the public to act, not just as a witness to the legal proceedings, but as an agent of justice that might succeed where (at least from their perspective) the law had manifestly failed. In Maxwell's hands, each of these trials becomes exemplary of the "politics of lost causes". Though Burke despaired of the acquittal of Hastings; Zola of the conviction of Dreyfus; and Arendt of the failure to make Eichmann stand trial in an international court (for her, the only one with the requisite legal standing to try crimes against humanity), they refused to give up a cause that, for all intents and purposes, had already been lost. In the face of the

(c) 2017 Macmillan Publishers Ltd. 1470-8914 Contemporary Political Theory Vol. 16, 4, 570-573 www.palgrave.com/journals 
failure of law, each turned to the public as the ultimate guarantor of justice in democracy and called upon it to exercise autonomous judgement.

Maxwell devotes one chapter each to the trials of Hastings, Dreyfus and Eichmann, and they make for absorbing reading in their own right. However, since her focus is less upon the historical details of each case than upon the way in which Burke, Zola and Arendt represent, engage and ultimately despair of the public, the substance of the book is perhaps best approached thematically. Two topics stand out as especially important in this regard: the first is that of the relationship between the public intellectual and the public to whom they appeal (or whom they seek to solicit for their "lost cause"), and the second is that of democratic failure.

With regard to the first, Maxwell draws a fascinating picture of a complex and thoroughly ambiguous co-dependency. As she is at pains to show, "the public" is never simply "there", waiting to be aroused in defence of a lost cause. It is up to the intellectual - here personified by Burke, Zola and Arendt - to solicit the kind of public that could hear the call to justice and respond accordingly. By its very nature, however, this act of solicitation is deeply fraught, subject to (at least) two different paradoxes: firstly, since the public is invariably implicated in the injustice that it is being called upon to correct, every solicitation is simultaneously an accusation against a bad public ("the masses") who failed to prevent injustice and an appeal to a good public ("the people") who might yet deliver justice; secondly, since the public being called to autonomous judgement remains reliant upon the public intellectual as truth teller, deference to authority is reinforced at the same moment as it is challenged. Each of Maxwell's chapters shines a different light upon these paradoxes and shows how the intellectual in question negotiates them. In Burke, we find a public whose naturally reliable sentiments have been corrupted by the spoils of colonialism and must be reawakened to sympathy (by Burke!); in Zola, a public inclined towards decency and justice, but susceptible to being misled by elites (other than Zola!); and in Arendt, a public divided between those who fall under the sway of "public opinion" (and thus judge falsely) and those who (by following Arendt's example!) are motivated by "public sprit" (and thus judge truly). Ultimately, however, it is the similarities that impress more than the differences. With all three figures, we see the same uneasy tension between the public who never quite lives up to expectations and the intellectual who never quite escapes the lure of elitism.

The second theme - of democratic failure - is similarly engaging and might well be regarded, not only as the real innovation of the book, but the place where Maxwell gets the most purchase upon the contemporary political scene. As it turns out, neither Burke, nor Zola, nor Arendt succeeds in their endeavours to solicit a public on behalf of justice. The British public let Hastings walk free, the French people stand by as Dreyfus is wrongfully imprisoned, and the "world public" that Arendt solicits in the hope of creating an international criminal court (to her mind the only one that could legitimately stand in judgement on crimes against 
humanity) never materialises. What appear, at first blush, to be failures of the law are thus also failures of democracy: "the people" are never there when you want them. The question that naturally arises for Burke, Zola and Arendt is thus what story to tell in the face of failure - one that gives up on democracy completely (what Maxwell describes as a "fatalistic narrative") or one that remains hopeful that a public might yet arise that will see the righting of old (and new) wrongs as its responsibility (what Maxwell describes as a "lost cause narrative")?

At the beginning of the Western tradition, according to Maxwell, Socrates makes the mistake of narrating a particular moment of democratic failure as the failure of democracy per se and gives it up as a hopeless case. Her interest in (and admiration for), Burke, Zola and Arendt, stems from the fact that they do not. On her account, Burke finds a way through his disappointment by inviting a future public to mourn his failure as a failure of sympathy and to use it as a means of building a critical regard for the suffering of distant others (a "chastened sympathy"); Zola, towards the end of his life, turns to writing, less as a means for revealing the truth to the public (as he did in "J'accuse"), than as a poetic device with which to enact the justice that never was and encourage the public yet-to-come to reflect upon what it might mean to tell the truth and do justice; and Arendt finds potential in comedy (beginning with her own ironic laughter in the face of Eichmann's mindboggling self-justifications), not only to reveal truth, but to give rise to a "we" (a community of laughers) who may yet take action and build new institutions on behalf of justice. Generalising from these pleas across time, Maxwell arrives at the notion of a "belated public" - a public that always arrives too late to prevent injustice, but which can always still do something to repair the injustices of the past and engage agonistically with the limitations of law in the present.

One could, of course, dispute Maxwell's characterisations - not least of all her depiction of Socrates who effectively becomes indistinguishable from Plato. But taking up the question of the "belated public" strikes me as the more interesting, and potentially more fruitful, line of critique. Lurking (but not really hiding!) in the shadows of Public Trials is a sense of the contemporary political moment as one of overriding despair. In the face of the enormous, and seemingly intractable, problems facing us today, writes Maxwell, "political actors" feel "overwhelmed and stuck" (p. 15), and "fatalistic narratives" hold sway over our "political imagination and practices" (p. 11). Democracy is on the ropes and the temptation to defer to expert opinion and countenance elite rule grows ever stronger (a point she later demonstrates with reference to the war on terror). In this climate, according to Maxwell, narratives that hark back to great moments of democratic triumph can seem so distant, so hopelessly unattainable, that they merely deepen our sense of despair. By contrast, "the politics of lost causes", precisely because it is born of failure, offers a way of keeping hope alive no matter how hopeless things appear. 
Maxwell's text is thus itself an attempt to solicit a public - one that will resist the temptations of fatalism even in "times of persistent democratic failure like our own" (p. 184). Her sincere hope, offered in the face of an American public that has become complicit in torture and an intellectual class resigned to failure, is that Public Trials will "productively orient us to the tragic dimensions of democratic life" and work to "politicise despair" (p. 185). Action, Maxwell is eager to remind us, can be significant even when it fails - provided, of course, we narrate it in the right way. But is that all there is? Is the politics of lost causes the best we can muster in dark times? When nothing goes right and injustice abounds, Maxwell implies, one can at least still hope that a public will one day appear that will respond - a "belated public" which will, by necessity, arrive too late to arrest the damage we are doing, but which may still deliver partial justice and revive forms of democratic solidarity. Perhaps. But, it is hard not to see this hope for the future as blind faith. The question I was left pondering at the end of this book was whether this vision of the "belated public" resists or feeds the fatalism that it wants to contest - can we afford to wait? Either way, I would recommend this book as a starting place for thinking about the hope "we", as democrats, invest in the public (and in ourselves as speakers for and members of that public) and what "we" can do in the face of profound disappointment.

Paul Muldoon

Monash University, Clayton, VIC 3800, Australia paul.muldoon@monash.edu 